\title{
A complex mode of screen translation: the case of advertise- ments on Spanish television
}

\author{
Cristina Valdés \\ University of Oviedo
}

This study on the translation of television commercials explores several aspects of this very specific audiovisual translation subtype. Firstly, it looks into dubbing and the language policies on Spanish television, which are issues affecting the decisions on the translation of television advertisements. Secondly, it approaches the notion of a TV 'spot' as an audiovisual text whose main components, image and sound, form a cohesive unity that is meant to trigger a persuasive effect, but may vary in translation. Finally, it analyses an example of a television spot, in English and in Spanish, focusing on the manipulation of the text when it is translated for Spanish television channels.

\section{Translating advertisements for television}

The translation of advertising texts designed for the television medium has been the object of study on very few occasions, and even less attention has been paid to the situation in Spain. The kind of texts to be analysed here are not long commercials, or the advertising materials introduced in TV programmes, but the short films known as 'spots', a type of screen texts whose translation has been scarcely dealt with. The spot is an audiovisual text which occupies a time slot on television, and in which a message is conveyed with the aim of enhancing the benefits or advantages of a particular product or providing information about it. Moreover, the spot is part of an advertising campaign with set goals and a significant economic and ideological background.

There have been numerous studies on advertising texts (Dyer 1988; Ortega 1997; Myers 1994; Saborit 1994; González Requena and Ortiz de Zárate 1995; Stewart and Furse 1986; Cook 1992), however, not much has been said about the translation of television advertising (de Pedro 1996, Valdés 2000, 2001, 2004), although it is often included in general studies about audiovisual translation. The definition of 'spots' above is the starting point for the present study and we are convinced this modality of translation should be included under the label of screen translation, alongside the localization of computer and multimedia products (Mayoral 2001: 20). Although Internet has been catching up as the main medium for promotion, television is still one of the most widely used communication media and thus one of the main channels of distribution of promotional campaigns. 


\section{A socio-historical approach to dubbing and language policy in Spain}

In Spain, in the particular case of advertising, as with other audiovisual texts, dubbing is the norm and hence the main translating mode of television commercials, although there have been attempts at using other translation modes for the advertising genre.

There are many studies on the history of dubbing in Spain, dating back to 1932 when many studios were set up to dub and add the soundtrack of films in Spain, particularly in Barcelona (Pereira 2001: 7). The conservative and protectionist politics in Spain, following the Civil War and throughout Franco's regime, led to strong support for dubbing and therefore the introduction of many foreign films, above all American, in dubbed version only. During that period and despite the technical advances and the huge number of dubbing companies that existed at the time, censorship was the principal feature of cinema translation. With the arrival of democracy many attempts at restoring and re-dubbing films again were made with the intention of correcting the censored translations. Meanwhile, advertisements were rarely translated, as the Spanish economy was reduced to national production and blocked to foreign competition and, therefore, advertising texts were $99 \%$ domestic.

The boom of dubbing in Spain in the 1980s and early 1990s arose from the arrival and immediate success of the video player and from the establishment of national and regional television stations. New studios were set up, not only in Madrid and Barcelona but also in Galicia, the Basque Country, Andalucia and the Valencian Community. Consequently a number of professionals such as translators, language correctors, dubbing actors, among others, were frequently on demand. Regional television stations played another important role in disseminating and normalising the Basque, Galician and Catalonian languages. However, in the early 1990s a number of reasons such as the excessive competition, the poor quality of dubbed products and the increase of Spanish-made audiovisual products led to a crisis in dubbing which, for many, still continues these days (Agost 1999, Pereira 2001). As Fuentes Luque (2001: 106) and Castro (2001: 137), quoted below, state, Spanish television channels have ceased to supervise the quality of translated audiovisual products:

Hace ya mucho tiempo que Televisión Española no supervisa la calidad de sus programas traducidos. La última cadena de habla española que lo hizo fue Canal+ y un recorte de presupuestos acabó con el otrora eficaz y beneficioso departamento de supervisión lingüística.

[For a long time now the Spanish Television Channel has ceased to supervise the quality of its translated programs. The last television channel in Spain which used supervision was Canal +, but a drastic 
budget cut put an end to an effective and necessary department of linguistic supervision] (translation CV).

Television is the medium preferred by advertisers and by the audience because of the advantages it offers, as television is watched by a large number of viewers in the world and it offers the resources to create advertisements made up of a combination of sound and moving image which trigger an immediate effect on viewers. Moreover, national television's monopoly ended in Spain in 1984 when the first regional channels started to broadcast their programmes. Another key point was the introduction in 1990 of commercial channels, thereby increasing the audiovisual output on offer in Spain considerably. Satellite emissions and digital networks have been very effective in this regard as well. Most of these commercial stations, national, regional or local, are funded or subsidised by advertising: in 1996 there were 900 local channels with their own local or regional advertising system (Ortega 1997: 125). This broad offer has led to the fragmentation of audiences and the reduction of advertising rates since the 1990s. In Catalonia, for example, most advertisements are broadcast in Catalan, as a study by the Catalan Institute of Sociolinguistics has pointed out:

In the advertising world, Catalan is used everywhere (audiovisual media, press, magazines) although most advertising on public highways is in Spanish, with the exception of institutional advertising which is mostly in Catalan[...].

In television, four public channels broadcast throughout Catalonian territory: the two Televisió de Catalunya channels (TV3, founded in 1983 , broadcasting a variety of programmes, and Canal 33, specialising more in cultural programmes and sport broadcasts). They broadcast exclusively in Catalan. Some 80 to $85 \%$ of advertising is in Catalan. The budget of the two channels was approximately ECU 190 million in 1992, 50\% of which came from advertising and $16 \%$ from grants. Televisión Española is broadcast in Catalonia on two channels (TVE1 and TVE2) which broadcast chiefly in Spanish. In 1992, TVE in Catalonia broadcast 37 hours of programmes per week in Catalan ${ }^{1}$.

Since the late 1980s, Spanish television has been obliged to undergo a process of internationalisation given the massive presence of foreign audiovisual products, including advertising campaigns. And, although the emission of advertising in television is limited by law, such regulation is hardly respected. Recently the European Commission has started proceedings against the Spanish Government, as television channels do not comply with the European directives on advertising (Television without Frontiers, 1994), which establishes a 12-minute slot per hour for television spots. Most Spanish television channels exceed the limit both in terms of the frequency and 
the duration of the advertising emission ${ }^{2}$. The Spanish General Law of Advertising (Law 34/1988, 11 November 1988) has a chapter on advertising creativity in which translation is not even mentioned, although the translation of a television ad is part of the advertising contract between all the agents involved, including translators, and thus subjected to the Law of Intellectual Property (Royal Decree 1/1996, 12 April); on the whole, the figure of the advertising translator seems to remain legally invisible, as there is a lack of legal protection for this professional.

Each television channel has its own regulations on advertising as well. In general, correct language usage is a prerequisite and coarse language is as good as prohibited. However, the multicultural and multilingual reality of Spain is also reflected in the variety of regional norms for advertising television broadcasting. All regional channels protect the use of their own languages to the detriment of Spanish, Basque being the only language on the Basque television station, for instance, which is an example of how the translation of adverts into the official languages of Spain is being promoted by legislation. The Reform of the Audiovisual Sector was approved by the Spanish Government on $24^{\text {th }}$ June 2005 to ensure cultural, social and political pluralism and to achieve a rapid transition from analogical technology to terrestrial digital technology ${ }^{3}$.

However, the European Television without Frontiers Directive (Directive 3 October $1989^{4}$ ) posed restrictions on national practices as it limited the number of spots emitted per day and presented a unification of criteria regarding the length of spots. This has had obvious and immediate consequences for advertising translation: if a commercial has to be translated into a language which requires more words to express the source text message and the length of the text has to be the same, the translator will be forced to make reductions and therefore to select material more carefully. Meanwhile, this directive has been amended in the Audiovisual Media Services without Frontiers Directive (2007) which aims "to provide a modern pro-competitive framework for Europe's providers of TV and TV-like services by, for example, giving more flexibility for financing audiovisual content by new forms of commercial communications".

Audiovisual norms establish time length differences for spots in different countries, for example, in Spanish television the norm is to broadcast a 20 second-spot, while in other countries such as the United Kingdom these texts tend to last 28 seconds $^{6}$. Despite this, some international channels such as the European EuroNews broadcast their advertisements in seven languages simultaneously?

Another factor is the use of foreign languages in advertising. The fact that Spanish young people have a greater command of foreign languages than people had decades ago has brought about the use of other languages rather than Spanish in advertisements, particularly English, as demonstrated by the vast number of non-translated spots, and this knowledge of foreign languages "influences people's preference of any particular Language Transfer method" (Luyken 1991: 116). Such spots address the 
younger segments of the population and advertisers employ relatively universal languages such as pop music or images, as icons of globalisation, which they suppose are likely to be interpreted in the same way everywhere by those segments of the population. French and Italian are also languages employed in television advertising for certain products such as perfumes, coffee and pasta (Valdés 2004).

Besides, English is also the working language of advertising, both for copywriting, mainly because English has a clear advantage in that it occupies less space in printed form (Wells et al. 1995: 748), and for business documentation in the sector. When translating from English into Spanish, for instance, about one third more space is required for the translation. Therefore, if the text is subtitled the translator will have to resort to condensation or the omission of certain elements, as shown below.

\section{The translation of advertisements for television stations in Spain: the process}

The process of translating advertisements has lately been transformed by the arrival of digital technologies, which have affected the choice of broadcast media, that is, the media mix, and the production techniques of television spots. Globalisation has also resulted in a greater homogenization of procedures and products, which has meant that the same advertising techniques, concepts, topics and images are shared by different audiences in the world.

Many different specialists participate in the production process of television commercials, but the translator plays a very minor role in the process. The basic production team of a spot involves: a producer, who is responsible for the coordination of all elements; a creative director in charge of the film; the accounts personnel; the copywriter; the soundtrack composer; an arranger, and an editor, who adds the final touch to the composition.

The advertiser gives this team the briefing and the idea is presented in the form of a script, with specifications about the music, the image, the dialogues and the duration of the spot. The headquarters of the advertising agency, usually in London or New York, send the campaign to the local offices in different countries, where a pre-test of the advertising material is carried out. This test uses the draft material and the rough version, most of the time written in English, and it aims to analyse the market reaction to the campaign. The script is a sort of visual planning with information about the required actors, music, setting, etc., and it is presented in a two-column format: on the right the information about the audio component and on the left a description of the visual elements. The next step comprises transferring the script to the storyboard with the film shots and presenting it to the client. In most recent times, an animatic with moving images and sound is shown to the advertiser. Nowadays the digital technologies allow for a 
much better presentation and easier modifications, since the process described above is mainly carried out with digitalised computer techniques. Finally, a film director is selected to shoot the film and the soundtrack is recorded and added to the film. If necessary, the film is translated and dubbed or subtitled.

In this process, translators often play a minor or external role. On the one hand, they have to preserve the ideas of the briefing and on the other make their translations acceptable to the target audience. Some translators have mentioned that when they are commissioned to translate a television commercial, they are rarely given the video, just the storyboard, making it is extremely difficult to see the global cohesive effect of the text. With digital technologies the translation process has changed significantly, of course, since the new format of the source text facilitates the process of revision and modification of the audiovisual text.

\section{The spot as an audiovisual text}

According to its internal structure and given its aim, the spot has a dramatic nature, as it is a short film shot in digital video format and divided into several scenes, or shots. The average length of a spot depends on the convention of the country (cf. supra). Spanish spots tend to last 20 seconds and they are composed of 4 or 6 scenes, while English commercials usually take 30 seconds and North-American ones, even more. The question of the duration of television spots is closely related to their effectiveness:

Persuasion is a complex process that takes time. Viewers must not only be induced to attend to the ad, but to also elaborate upon it in their minds. This capability is surely absent in the 10- and 15-second ads and it is unclear whether 30-second ads do it particularly well either. (Lowrey, Shrum \& McCarty 2005: 129-130)

As in other dramatic texts, there are actors, who may be either professional or famous people endorsing the product, or so-called spokesthings. The main prop is the product represented by the object itself or by its logo. Occasionally it can be alluded to with a certain colour or a symbol, as in the case of Lancôme products whose circumflex is enough for the spectator to associate the symbol with the brand. These are aspects of the text type that should be known by expert translators, as experts in the text type they are translating. If the overall meaning of the spot resulting from the relationship of the elements fails, the whole meaning of the text fails as well. That is, for example, if the voice of the character in the spot reproduces an accent which does not correspond visually to the character appearing on screen, the overall meaning the text wants to convey falls flat. Likewise, the internal cohesion of the visual component and the lyrics and tune of a spot con- 
tribute to the overall meaning of the audiovisual text, as described in Valdés (2005).

The semiotic complexity of spots compels the translators to consider a varied number of codes (chromatic, typographic, or cinematic), essential to understand, and hence to render, the meaning of the text, whose interpretation is culture-bound. It is well known that viewers do not assign the same values to - say - a colour or a gesture in different contexts. Therefore the promotional language which characterises advertisements does not only trigger a persuasive effect by means of words, but also through many other means, such as music, colour, rhythm, etc. Promotional language is considered a kind of language which characterises not only advertisements but also many other text types with the primary function of promotion, such as manuals, leaflets, tourist brochures, webpages, among others.

Chaume (2001) refers to audiovisual texts as "multidimensional texts" since there are several codes of meaning, which use two different channels of communication at the same time and in the same space. The coherence of the whole audiovisual text depends, therefore, on the cohesion mechanisms between verbal and visual elements and requires physical support to communicate the semiotic complexity of an audiovisual advertising text. This complexity of a television advertisement mainly resides in the two components detailed below, an acoustic and a visual one, broken down into further elements (Valdés 2001: 232):

Table 1: The television spot

\begin{tabular}{|c|c|c|c|}
\hline \multicolumn{2}{|c|}{ Audio } & \multicolumn{2}{|c|}{ Visual } \\
\hline Verbal & Non-verbal & Verbal & Non-verbal \\
\hline $\begin{array}{l}\text { Actors' voice } \\
\text { (original or } \\
\text { dubbed) }\end{array}$ & Music & $\begin{array}{l}\text { Words writ- } \\
\text { ten on screen } \\
\text { (brand name, } \\
\text { subtitles, } \\
\text { posters...) }\end{array}$ & $\begin{array}{l}\text { Objects, mov- } \\
\text { ing people... }\end{array}$ \\
\hline Off voice & Sound effects & Logo & Logo \\
\hline \multirow[t]{3}{*}{$\begin{array}{l}\text { Lyrics of } \\
\text { songs }\end{array}$} & Silence & $\begin{array}{l}\text { Lyrics of } \\
\text { songs }\end{array}$ & Typography \\
\hline & & & Light intensity \\
\hline & & & Colours \\
\hline
\end{tabular}


The combination of image and sound depends on the persuasive goal of a given spot and the advertisement design influences the way the text is perceived. Receptors have an active role as they assign a particular meaning to the different elements of the commercial by associating them with other parameters that are culturally internalised. The text is understood as a textin-context and hence the interpretation will be different from one particular user-context to another. If the text is translated for an international target through global media and translated into different languages simultaneously, the interpretative process is highly complicated. In audiovisual advertising this is very much the case: the audience is a relatively heterogeneous group, anonymous and belonging to different cultures, in particular in international campaigns. What is desirable on the part of advertisers and translators, in order to make their advert effective, is to achieve the acceptability of the target text by making it coherent (Valdés 2000).

One interesting question to consider concerns the feedback on advertising campaigns which use multimedia. The reaction of the audience to advertisements is difficult to measure, although there are sophisticated methods of marketing analysis which quite accurately offer feedback data on a campaign. One of the examples comes from the Internet, as the company Teknoland created a revolutionary system of audience control, called teknoad, through the banners their clients have in their web site. This allowed them to monitor their clients' campaigns effectively and continuously, as the system provided them with data about the number of website visitors which reached the website from one link or another ${ }^{8}$. In television advertising there are other systems of audience measuring which make it possible to determine the best time of day to broadcast the commercial (Wells 1997).

The cost element is always crucial in international advertising: the cheaper the better, provided that the text is comprehensible and effective in the target market. Very often in television advertising translation, the film basically remains unchanged and the words are translated and dubbed, costeffectiveness being one of the main reasons for choosing the dubbing mode. When necessary, a few terms such as the strapline or pay-off line that comes at the end of the spot are translated into the target language and added on the original image, as in the Audi car commercials where the strapline "Vorsprung durch Technik" has been translated as "A la vanguardia de la técnica". McDonald's and Coca-Cola, for example, record the music for their campaigns and make a soundtrack for each country in the target language. Given their expertise in dubbing and the quality of the product they offer, Spanish studios are often commissioned to do the dubbing. What is more, they are much cheaper than their North American counterparts. 


\section{An example of a television spot: the text analysis}

\subsection{The manipulation of the text}

Building on the premise that every translation entails a series of textual transformations (Delabastita 1989) and that a spot is a multidimensional text (Chaume 2001; Zabalbeascoa 2001; Valdés 2001), it is essential to take into account the modifications which take place in the audio and visual components when the text is translated into another language and for another target audience. Chaume (1997) points out that the verbal component is designed and translated with the actors, the fiction, the audience and the oral character of the film in mind, while the visual component should represent a realistic world, the movements the audience sees on screen should be meaningful and coherent with the action. Occasionally the meaning of nonverbal elements is also translated through verbal elements. As Chaume (1998: 18) explains, "In our texts the visual narration cannot be manipulated, so translators will have to find isotopic solutions in the verbal subtext, where they are allowed to manipulate". Besides, if the translation involves a change from a printed medium to an audiovisual one, the text will necessarily undergo several variations or adaptations, depending on the medium constraints. In the case of television, there may be changes in the target text which affect the oral component or the visual component of the commercial: the intonation, accent, social and geographical language varieties or the lyrics of the songs, and the modifications of actors, different camera movements or the different organization of elements on screen may trigger a different effect and thus interpretation by the target audience.

In order to illustrate these aspects and to exemplify these transformations, I will analyse one television commercial, chosen after viewing a series of spots recorded from several national and international television channels. A comparison will be made between the spot broadcast on a national Spanish television channel and the same spot on an international television channel.

Having dubbing as the main translation mode, the different reading speed of English and Spanish and the different duration of the commercial naturally lead to adjustments such as the omission of information. In the case of television advertisements, their short duration, 20 to 30 seconds, frequently forces the translator to choose what to leave out and what to preserve (Valdés 2004). The following pair of parallel commercials are intended to promote the new Gillette Sensor Excel razor blades (Ad agency BBDO, New York) in a Spanish national television station (Tele5) and in an international satellite-broadcast channel (Cartoon Network). In other channels for Cataluña or Galicia, the same spot dubbed into Spanish is used. Although they seem to be exact copies of each other, one in English and the other in Spanish, a close study of the spot reveals several differences: 
- The duration is different, in conformity with the conventions of each target market: the Spanish one lasts for 20 seconds, while the English text takes 30 seconds of the time slot. This makes the translator to be particularly sensitive and adjust the length of the text to the time constraint of the target television channel;

- $\quad$ Several scenes have been changed while preserving the global meaning of the text;

- Visual action is closely linked to words and this is preserved when the advertisement is shortened.

A new technology, common in cinema films, has been used in this particular spot: the digital fix-it, which consists of 'mending' the source text, instead of creating a new film. This has the advantage of reducing costs. This spot, titled Arm Switch, has undergone a series of adjustments to make it suitable for the Spanish audience and culture, in terms of language and adaptation to some medium norms, e.g. the duration of the spot. As an article on digital fix-its states:

The commercial, in which mirror-imaged men exchange arms and razors, is running in North America and Europe. Rather than reshooting the commercial with actors who could speak different languages needed for the international versions, VideoWorks decided to reposition the lips of the actors, painting in the physical details which would approximate the various foreign languages.

Using Discreet Logic's Flint running on a Maximum Impact Indigo, artist Tree O'Donnell isolated the actors' lip movements, recorded the lips' position when certain vowels and consonants were spoken, cut those positions out, and then pasted them together to construct the appearance of Spanish, Italian, and French speech. "It saved the agency a lot of money," says VideoWorks, Inc. general manager Steve Villante. "And not only that, but to change images without reshooting is a benefit to all involved because of the amount of time saved as well." VideoWorks, Inc. has been involved with other alterations as well, using the Flint system to change wording on deodorant labels for international campaigns because of certain terms not used within European cultures",

This new system certainly has implications for dubbing and lipsynchronization, as it is not necessary to reshoot the film, just to make modifications when strictly necessary. However, the translator still faces the difficult decision of making choices and selecting the material to be suppressed given the time constraints of the medium. What are the reasons that lead to the elision of certain elements instead of others? 


\subsection{Textual analysis}

The Gillette Sensor Excel spot script exemplifies translators' strategies with respect to the preference of one term over another. The table below shows the script in the original English text, the dubbed version as heard in the Spanish spot, as well as a description of what can be seen on screen in both texts.

Table 2: The Gillette Sensor Excel spot

\begin{tabular}{|c|c|c|c|c|}
\hline & $\begin{array}{c}\text { ON SCREEN } \\
\text { (visual) }\end{array}$ & $\begin{array}{c}\text { AURAL } \\
\text { ENGLISH } \\
\text { TEXT } \\
\text { (30 seconds) }\end{array}$ & $\begin{array}{c}\text { ON SCREEN } \\
\text { (visual) }\end{array}$ & $\begin{array}{c}\text { AURAL } \\
\text { SPANISH } \\
\text { TEXT } \\
\text { (20 seconds) }\end{array}$ \\
\hline 1 & $\begin{array}{l}\text { Two men are } \\
\text { shaving, one on } \\
\text { each side of the } \\
\text { screen. } \\
\text { They switch } \\
\text { arms. }\end{array}$ & $\begin{array}{l}\text { Gillette Sensor } \\
\text { Excel. } \\
\\
\text { Now it will } \\
\text { change your } \\
\text { mind. }\end{array}$ & $\begin{array}{l}\text { The product } \\
\text { appears on } \\
\text { screen. Then, } \\
\text { the two men. } \\
\text { They switch } \\
\text { arms. }\end{array}$ & $\begin{array}{l}\text { Prueba la nue- } \\
\text { va Sensor Ex- } \\
\text { cel. }\end{array}$ \\
\hline 2 & $\begin{array}{l}\text { The dark- } \\
\text { haired man is } \\
\text { shaving. } \\
\text { Image of razor } \\
\text { blades }\end{array}$ & $\begin{array}{l}\text { After one shave } \\
\text { of Gillette Sen- } \\
\text { sor Excel we } \\
\text { bet you won't } \\
\text { go back } \\
\text { because only } \\
\text { Sensor Excel } \\
\text { has protective } \\
\text { microfilms for } \\
\text { extra comfort. }\end{array}$ & $\begin{array}{l}\text { The dark- } \\
\text { haired man is } \\
\text { shaving . } \\
\text { Image of razor } \\
\text { blades }\end{array}$ & $\begin{array}{l}\text { Sólo Sensor } \\
\text { Excel tiene } \\
\text { micro-tensores } \\
\text { para darte más } \\
\text { suavidad }\end{array}$ \\
\hline 3 & $\begin{array}{l}\text { The dark- } \\
\text { haired man is } \\
\text { enjoying his } \\
\text { shave. } \\
\text { Close-up of the } \\
\text { man's face }\end{array}$ & $\begin{array}{l}\text { And has self- } \\
\text { adjusting } \\
\text { blades } \\
\text { for extra close- } \\
\text { ness. }\end{array}$ & $\begin{array}{l}\text { The dark- } \\
\text { haired man is } \\
\text { enjoying his } \\
\text { shave. } \\
\text { Close-up of the } \\
\text { man's face }\end{array}$ & $\begin{array}{l}\text { para darte más } \\
\text { apurado. }\end{array}$ \\
\hline 4 & $\begin{array}{l}\text { The blond man } \\
\text { tries the other } \\
\text { disposable } \\
\text { razor but he }\end{array}$ & $\begin{array}{l}\text { Disposables } \\
\text { don't. }\end{array}$ & $\begin{array}{l}\text { The blond man } \\
\text { tries the other } \\
\text { disposable } \\
\text { razor but he }\end{array}$ & $\begin{array}{l}\text { Las desech- } \\
\text { ables no. }\end{array}$ \\
\hline
\end{tabular}




\begin{tabular}{|c|c|c|c|c|}
\hline & $\begin{array}{l}\text { doesn't like it. } \\
\text { The dark man } \\
\text { strokes his face } \\
\text { to feel his } \\
\text { shave. }\end{array}$ & $\begin{array}{l}\text { And Sensor } \\
\text { Excel gets } \\
\text { more shaves } \\
\text { per blade than } \\
\text { any disposable. }\end{array}$ & doesn't like it. & \\
\hline 5 & $\begin{array}{l}\text { The blond one } \\
\text { complains. }\end{array}$ & Excuse me! & & \\
\hline 6 & $\begin{array}{l}\text { The camera } \\
\text { moves towards } \\
\text { the brand } \\
\text { name. } \\
\text { The dark- } \\
\text { haired man } \\
\text { goes away with } \\
\text { Gillete Sensor } \\
\text { Excel. }\end{array}$ & $\begin{array}{l}\text { We bet you } \\
\text { won't go back } \\
\text { to disposables. }\end{array}$ & $\begin{array}{l}\text { A disposable } \\
\text { razor different } \\
\text { from Gillette } \\
\text { Sensor Excel } \\
\text { appears on } \\
\text { screen } \\
\text { Image of a } \\
\text { Gillette Sensor } \\
\text { Excel. }\end{array}$ & $\begin{array}{l}\text { Prueba Gillette } \\
\text { Sensor Excel }\end{array}$ \\
\hline 7 & $\begin{array}{l}\text { The blond man } \\
\text { wants the razor } \\
\text { back. }\end{array}$ & $\begin{array}{l}\text { Hey! I want my } \\
\text { Sensor Excel } \\
\text { back! Hey! }\end{array}$ & $\begin{array}{l}\text { The blond man } \\
\text { wants the razor } \\
\text { back. }\end{array}$ & $\begin{array}{l}\text { ¡Eh! ¡Dame mi } \\
\text { Sensor Excel! }\end{array}$ \\
\hline 8 & $\begin{array}{l}\text { The product } \\
\text { and the slogan. }\end{array}$ & $\begin{array}{l}\text { Gillette. The } \\
\text { Best A Man } \\
\text { Can Get }\end{array}$ & $\begin{array}{l}\text { The product } \\
\text { and the slogan. }\end{array}$ & $\begin{array}{l}\text { Gillette. Lo } \\
\text { Mejor para el } \\
\text { Hombre. }\end{array}$ \\
\hline
\end{tabular}

The transcription and parallel study of the visual and acoustic components of the text reveal that:

- Given the shorter duration of the Spanish text, the translator has had to suppress redundant information which in the English source text serves to emphasise an idea such as "And Sensor Excel gets more shaves per blade than any disposable" or "We bet you won't go back to disposables", which are mentioned twice in the English spot. This is due to the fact that the main appeal of the marketing campaign was based on the idea that after using a Gillette Sensor Excel razor blade, customers would not use any other kind of razor blades, as the business director of blades and razors for Gillette explained: "We called it the Challenge program: "Try Sensor Excel and you won't go back" (Rifkin 1999). Therefore, the Spanish target text gains 
speed, but loses the strengthening parts of the message and thus emphasis on the advantages of the product;

- Likewise, a few shots of the original film have been suppressed to adjust the film to the time constraints of Spanish television (with shorter spots). And others have been added in the Spanish target text, the image of razors, perhaps to compensate for the textual cuts that have been made elsewhere. Thus, the extra presence of non-verbal elements is used to compensate for verbal deletions;

- $\quad$ Something to take into account is the syllabic quantity and rhythm of languages, which differ in English and Spanish. The reading speed of the off-voice in the Sensor Excel English spot is higher than in the Spanish text, where the actor needs more time to pronounce the syllables clearly enough to be understood by the audience.

It should be borne in mind that, in such condensed and brief texts as commercials, the audience's attention needs to be caught, through exploiting non-verbal resources such as music, rhythm or the quality of the voice heard, and through visual resources, i.e. the impact of images. In the Gillette Sensor Excel the visual effect of arm switching and the quick rhythm of the film make it attractive to viewers in both spots. This arm switch, which is also the name of the marketing campaign, reinforces the idea that, once consumers change to the new Gillette Sensor Excel razor blade, they refuse to use any other product of the kind.

The last shot of the spot presents the well-known Gillette slogan printed on screen: "Gillette. The Best A Man Can Get", which is translated into Spanish as "Gillette. Lo Mejor para el Hombre", literally "Gillette. The best for men", thus preserving the main message, which has become a familiar slogan for the Spanish audience. However, as seen on screen, this slogan looks unusual to the eyes of the target audience. Why? The reason is the capitalisation of initial letters, which is wrong in Spanish. A spelling convention of Spanish has been broken.

The cohesion of elements has been achieved with a different distribution of elements. However, the necessary synchrony between what is seen and what is said has been maintained, as can be observed in the textual comparison above. Extra emphasis is placed on the relationship between the visual action of using Gillette Sensor Excel blades and the aural verbal text, emphasis which is accomplished through the redundant appearance on screen of the element which is mentioned by the off-voice.

Although dubbing seems to be the audiovisual translation norm in Spain for advertising as well as for other texts, other translation modes such as subtitling, voice-over or non-translation are occasionally employed in the Spanish context with different purposes (Valdés 2001), posing the difficulties and advantages characteristic of each translation mode. In television advertising, dubbing is abandoned in favour of subtitling when there is a wish to reinforce the global and/or foreign connotation of the product or to enhance the presence of somebody famous on screen, allowing viewers to 
hear the authentic voice of the character. Similarly, a voice-over version is chosen when the characters seen and heard in the spot are well-known celebrities who tell the audience they have experienced the product. Lately, the audiovisual advertising industry has rather devised international campaigns on screen employing world-known icons from sport or fashion in television sports and reducing the number of words and verbal messages to a minimum. When a language is used, English is the preferred one and songs replace spoken messages. In the television advertisement of Gillette Sensor Excel, the main translation mode is dubbing but there are other translation types that also occur, as, for example, the replacement of the English strapline on screen for its translated version "Gillette. The Best A Man Can Get". Gradually most global campaigns have introduced television commercials mostly in English - but some in French - to harmonise the company's communication and marketing approach everywhere. In Spanish television channels, however, most products are advertised by means of dubbed texts, with the exception of the global campaigns above mentioned (Calvin Klein, Nike, Lancôme, among others).

\section{Conclusions}

As the advertising industry is a highly internationalised activity, the marketing strategies for a particular campaign include issues such as language choice and translation. Rifkin (1999) points out that Gillette's global approach was based on some principles like these two:

To facilitate a smooth global introduction, all packaging, point of sale and other promotional and support material had to be the same, simply translated into 30 languages for other geographies .

In the same vein, all marketing and advertising was based on a single campaign that was released in every market, again with minor local adjustments and translations.

The Gillette approach is an example of the prevailing communication approach of most international products, which has an effect on the translation mode. But the choice also stems from other socio-cultural factors such as the political role of a particular language or the degree of acceptance of foreign languages in advertising. In Spain, the language policies of the different geographical and cultural entities as well as the language policy of each television channel affect the production and decisions concerning the advertisements of local products or locally-produced television spots in the target language of the region or autonomous community. However, the vast majority of television commercials remain dubbed in the Spanish territory.

The promotion of the official languages other than Spanish, as well as the accessibility of audiovisual products to a larger audience, can be further enhanced by the improvement of distribution and by the implemen- 
tation of digitization of screen texts, including television advertisements. As Gambier points out (2003: 181):

Dubbing could also take advantage of digitization, in at least two ways: to improve the quality of sound, thanks to the possibility of analyzing and synthesizing actors' voices, and retain the original soundtrack irrespective of the specific source language; and to make use of the potential manipulation of original images, especially the lips.

Thus, the recording of a soundtrack in the different languages of the Spanish territory as well as the manipulation of the visual component can be achieved by the application of new technologies, and therefore lead to the production of a more accessible and more adequate and acceptable audiovisual product.

Further and more specific studies are required into audiovisual advertising translation, particularly as part of a major project about audiovisual translation norms in Spain, which have been successfully developed by several scholars (Mayoral, Agost, Zabalbeascoa, Chaume, Díaz-Cintas, among others). However, most of these projects have often left aside the presence of screen promotional texts such as television spots. Moreover, we still need to think of audience design and reception studies in television advertising as two challenges for future research in the field of translation. Finally, there is still a lack of serious approaches to the translation of promotional texts in a multimedia medium, which is gradually becoming one of the most significant and rich areas of professional translation. Further study would enrich the research panorama of screen translation.

\section{Bibliography}

Agost, Rosa (1999). Traducción y doblaje: palabras, voces e imágenes. Barcelona: Ariel Practicum.

Agost, Rosa (2001). "Traducción, ideología y norma: entre la institución y el destinatario". TRANS, n. $5,127-142$.

Castro Roig, Xosé. (2001). "Cuestiones sobre la norma culta y los criterios de calidad para la traducción de doblaje y subtitulación en España”. Chaume, F. \& R. Agost (eds). La traducción de los medios audiovisuales. Castelló: Universitat Jaume I, 135-140.

"Catalan in Catalonia" http://www.uoc.es/euromosaic/web/document/catala/an/i1/i1.html\#3.4. (last visited on 24 August 2007).

Chaume, Frederic (1997) "Translating non-verbal information in dubbing”. F. Poyatos (ed.). Nonverbal Communication and Translation. Amsterdam/Philadelphia: Benjamins, 315-326.

Chaume, Frederic (2001). "Vínculos de cohesión entre la narración verbal y la narración visual en la traducción de textos audiovisuales". L. Lorenzo \& A. Pereira (eds). Traducción subordinada (I). El doblaje (inglés-español-gallego). Vigo: Universidade de Vigo, 69-83.

Chaume, Frederic. \& Rosa Agost (eds) (2001). La traducción de los medios audiovisuales. Castelló: Universitat Jaume I.

Cook, Guy (1992). The Discourse of Advertising. London: Routledge.

Delabastita, Dirk (1989). "Translation and Mass Communication: Film and T.V. Translation as Evidence of Cultural Dynamics". Babel 35:4, 193-217.

Dyer, Gillian (1988). Advertising as Communication. London: Routledge. 
European Comission (2007). "Audiovisual Media Services without Frontiers Directive" http://ec.europa.eu/avpolicy/reg/tvwf/modernisation/proposal_2005/index_en.htm (last visited on 24 August 2007)

European Comission (2005). "Comparative study on the impact of control measures on the televisual advertising markets in European Union Member States and certain other countries" On line at http://ec.europa.eu/avpolicy/info_centre/library/studies/index_en.htm (last visited on 24 August 2007)

European Comission (1989). Television Without Frontiers Directive 89/552/EEC. http://eurlex.europa.eu/LexUriServ/LexUriServ.do?uri=CELEX:31989L0552:EN:HTML (last visited on 24 August 2007)

Fuentes Luque, Adrián (2001). La recepción del humor audiovisual traducido: estudio comparativo de fragmentos de las versiones doblada y subtitulada al español de la película Duck Soup, de los Hermanos Marx, PhD thesis. Granada: Universidad de Granada.

Gambier, Yves (ed.) (1997). Language Transfer and Audiovisual Communication. A Bibliography. University of Turku: Centre for Translation and Interpreting.

Gambier, Yves (2003). "Introduction: Screen transadaptation, Perception and Reception". The Translator, Vol. 9(2). November 2003, 171-190.

González Requena, José \& A. Ortiz de Zárate (1995). El espot publicitario. Las metamorfosis del deseo. Madrid: Ediciones Cátedra. Colección Signo e imagen.

"Publicidad". http://www.euronews.net/index.php?page=advertising\&lng=5. (last visited on 24 August 2007)

Lorenzo, Lourdes \& Ana M. Pereira (eds) (2000). Traducción subordinada (I). El doblaje (Inglésespañol/galego). Vigo: Universidade de Vigo.

Lowrey, Tina M., L. J. Shrum, \& John A. McCarty (2005) "The Future of Television Advertising," in Kimmel, Allan J. (ed.) Marketing Communication: Emerging Trends and Developments, New York: Oxford University Press, 113-132.

Luyken, Georg-Michael (1991). Overcoming Language Barriers in Television: Dubbing and Subtitling for the European Audience. Manchester: The European Institute for the Media.

Mayoral, Roberto, Dorothy Kelly \& Natividad Gallardo (1986). "Concepto de "traducción subordinada" (cómic, cine, canción, publicidad). Perspectivas no lingüísticas de la traducción (I)". Fernández, F. (ed.) (1986) Pasado, presente y futuro de la lingüística aplicada en España. Actas del III Congreso Nacional sobre Lingüística Aplicada. AESLA. Valencia: Servicio de Publicaciones. April 1986, 95-105.

Mayoral, Roberto (2001). "Campos de estudio \& trabajo en traducción audiovisual”. Duro Moreno, M. (coord.) La traducción para el doblaje y la subtitulación. Madrid: Cátedra, 19-45.

Mooij, Marieke de (2001). "Convergence and divergence in consumer behaviour". Admap. October 2001, 30-33.

Myers, Greg (1994). Words in Ads. London : Edward Arnold.

Ortega, Enrique (1997). La comunicación publicitaria. Madrid: Ediciones Pirámide.

Pedro, Raquel de (1996). "Beyond the Words: The Translation of Television Adverts". Babel 42: 1, $27-45$

Pereira, Ana M (2001). “Doblaje y traducción en España y en Galicia: su historia”. Lorenzo, L. \& A. Pereira (eds) Traducción subordinada (I). El doblaje (inglés-español-gallego). Vigo: Universidade de Vigo, 7-16.

Rifkin, Glenn (1999). "MACH 3: Anatomy of Gillette's Latest Global Launch”. Strategy + business. http://www.strategy-business.com/press/16635507/16651. (last visited on 24 August 2007)

Saborit, José (1994). La imagen publicitaria en televisión. Madrid: Ediciones Cátedra. Colección Signo e imagen.

Speier, Michael (1997). "Effects to the Rescue: Fix-its Have Become a Mainstream Hollywood Practice... and Facilities Couldn't Be Happier (and Busier)". http://effectsgraphics.videosystems.com/ar/video_effects_rescue_fixits/. (last visited on 24 August 2007)

Stewart, David W. \& David H. Furse (1986). Effecctive TV Advertising. Lexington: Lexington Books.

Valdés, Cristina (2000). "Reception Factors in Multimedia Translation: The Case of Advertisements". Chesterman, A., N. Gallardo \& Y. Gambier (eds). Translation in Context. Selected Contributions from the EST Congress, Granada 1998. Amsterdam/Philadelphia: John Benjamins, 271-280. 
Valdés, Cristina (2001). "Extranjerización y adaptación en la traducción de espots publicitarios". Chaume, F. \& R. Agost (eds). La traducción audiovisual en España. Castelló: Servei de Publicaciones de la Universitat Jaume I, 183-192.

Valdés, Cristina (2004). "Una aproximación a la traducción de espots televisivos: un ejemplo de publicidad audiovisual”. Pereira, A. M. \& L. Lorenzo (eds). Traducción subordinada inglés-español/galego: la traducción publicitaria. Vigo: Universidade de Vigo, 231-239.

Valdés, Cristina (2004). La traducción publicitaria: comunicación y cultura. Colección: La Aldea Global. València: Universitat de València. Castelló de la Plana: Publicacions de la Universitat Jaume I. Barcelona: Universitat Pompeu Fabra. Bellaterra: Universitat Autòmoma de Barcelona. Servei de Publicacions, D.L.

Valdés, Cristina (2005). "Catchy tunes: the oral component in advertisements as a challenge to translators". Cruz, L. et al (eds) Traducir e interpretar: visions, obsesiones y propuestas. Las Palmas de Gran canaria: Universidad de Las Palmas de Gran Canaria.

Wells, William D (1997). Measuring Advertising Effectiveness. Mahwah, New Jersey: Lawrence Erlbaum Associates.

Wells, William D., John Burnett \& Sandra Moriarty (1995) ( $3^{\text {rd }}$ ed.) Advertising. Principles and Practice. New Jersey: Prentice Hall.

Zabalbeascoa, Patrick (2001). "El texto audiovisual: factores semióticos y traducción”. Sanderson, J. D. (ed.). ¡Doble o nada! Actas de las I y II Jornadas de doblaje y subtitulación. Alicante: Universidat d'Alacant, 113-126.

1 "Catalan in Catalonia" Published online at http://www.uoc.es/euromosaic/web/document/ catala/an/i1/i1.html\#3.4 (last visited on 24 August 2007).

2 "La CE expedienta a España por superar los límites de publicidad en televisión". Published online at http://www.lavanguardia.es/lv24h/20070710/51372627502.html (last visited on $24 \mathrm{Au}-$ gust 2007).

3 My translation of the following text: "With the aim to promote and consolidatie a sustainable, independent and one that ensures social and political pluralism, as well as to achieve a rapid, organized and feasible transition from the analogical technology to the terrestrial digital technology". (http://www.sindicato-periodistas.es/profesion_ver.php?id=40) (last visited on 24 August 2007).

4 Television Without Frontiers Directive 89/552/EEC, Published online at http://eurlex.europa.eu/LexUriServ/LexUriServ.do?uri=CELEX:31989L0552:EN:HTML (last visited on 24 August 2007).

5 "Presenting the new Audiovisual Media Services without frontiers Directive: Frequently asked questions" Published online at http://europa.eu/rapid/pressReleasesAction.do?reference=MEMO $/ 07 / 206 \&$ format $=$ HTML\&aged $=0 \&$ language $=E N \&$ guiLanguage $=$ en (last visited on 24 August 2007).

6 For a complete report on the different timing for advertising in different countries see "Comparative study on the impact of control measures on the televisual advertising markets in European Union Member States and certain other countries." http://ec.europa.eu/avpolicy/info_centre/library /studies/index_en.htm (last visited on 24 August 2007).

7 "Publicidad" Published online at http://www.euronews.net/index.php?page=advertising\&lng=5 (last visited on 24 August 2007).

8 "El efecto económico de Internet. Anuncios a la carta" Published online at http://www.glreach.com/es/ed/art/doc6.htm (last visited on 24 August 2007).

9 "Effects to the Rescue: Fix-its Have Become a Mainstream Hollywood Practice...and Facilities Couldn't Be Happier (and Busier).” http://effectsgraphics.videosystems.com/ar/video_effects_ rescue_fixits/ (last visited on 24 August 2007) 